СПИСАНИЕ НА БЪЛГАРСКОТО ГЕОЛОГИЧЕСКО ДРУЖЕСТВО, год. 82, кн. 3, 2021, с. 259-261

REVIEW OF THE BULGARIAN GEOLOGICAL SOCIETY, vol. 82, part 3, 2021, p. 259-261

\title{
Holocene fluctuations of the Black Sea level and human activities along the south Black Sea coast
}

\section{Холоценските флуктуации на черноморското ниво и човешките дейности по Южното Черноморие}

\author{
Dimitar Sinnyovsky \\ Димитър Синьовски \\ University of Mining and Geology “St. Ivan Rilski”1700 Sofia; E-mail: sinsky@mgu.bg
}

\begin{abstract}
Holocene fluctuations of the Black Sea level have played a significant role in the existence of the Black Sea poliscities. The high sea-level during the Novochernomorian transgression is followed by the Phanagorian regression when the sea level reached its minimum of $3 \mathrm{~m}$ below the modern sea level during the antiquity (Roman Age). Then, on the west coast of Mandra Lake the Roman polis Deultum was founded which became a flourishing port. The discrepancy between the low sea level and ancient navigation activity in Mandra Lake is a challenge for further investigations of the Holocene sediments.
\end{abstract}

Keywords: Holocene terraces, transgressions, regressions, ancient ports.

\section{Геоложки предпоставки}

Холоценските флуктуации на морското ниво са добре изучени по украинското и руското крайбрежие, където са идентифицирани отчетливо две трансгресии и една регресия. След стабилизирането на високо морско ниво в началото на Холоцена преди около 7000 г. се проявява Новочерноморската трансгресия (Fedorov, 1956), която достига своя максимум от 4-5 m над съвременното ниво преди 5600-4300 г. (Бронзовата епоха). Новочерноморската тераса, съответстваща на това ниво, е добре изразена по Странджанското крайбрежие (Fedorov et al., 1962). Преди 4100 г. морското ниво сьвпада приблизително с днешното, а преди 2500 г. започва Фанагорийската регресия (Fedorov, 1956), която предизвиква спад до $3 \mathrm{~m}$ под съвременното морско ниво. След VI в. започва последната в историята на Земята трансгресия, наречена Нимфейска (Fedorov, 1959), когато морското ниво отново се повишава и преди около 1000 г. достига до 1,5-2,0 т над съвременното.

\section{Археологически данни}

Елинската колонизация по бреговете на Средиземноморието започва от VIII в. пр. н. е. Ин- тересът към древния Понтос (Черно море) се проявява по-късно, след заселването на южните части на Балканския и Апенинския п-в, както и п-в Мала Азия. Археологическите проучвания показват, че много от древните градове, създадени по време на гръцката колонизация, днес се намират под морското ниво, като напр. древногръцката колония Херсонес на Кримския п-в. По нашето крайбрежие също има редица примери за потопени древни селища. В холоценските наслаги между Варненското езеро от Варненския залив на $9 \mathrm{~m}$ дълбочина е намерена дъбова лодка и останки от наколни жилища от ранната Бронзова епоха отпреди 4500 г., а на 2-2,5 m под водата е открита 4,5 m висока вълноломна стена с дължина 250 m (Popov, Mishev, 1974). При разширяването на канала между Варненското езеро и морето на 2-3 m дълбочина е открита стена и амфори от елинистичната, древноримската и ранновизантийската епоха в древно селище, различно от Одесос. Последното разширение на канала през 2019 г. предостави нова информация за холоценските отложения (Sinnyovsky, 2020b). Останки от потопени селища има също при Несебър, Созопол, Китен, Атия и устието на p. Ропотамо, а при Поморие на 2-3 т под вода- 

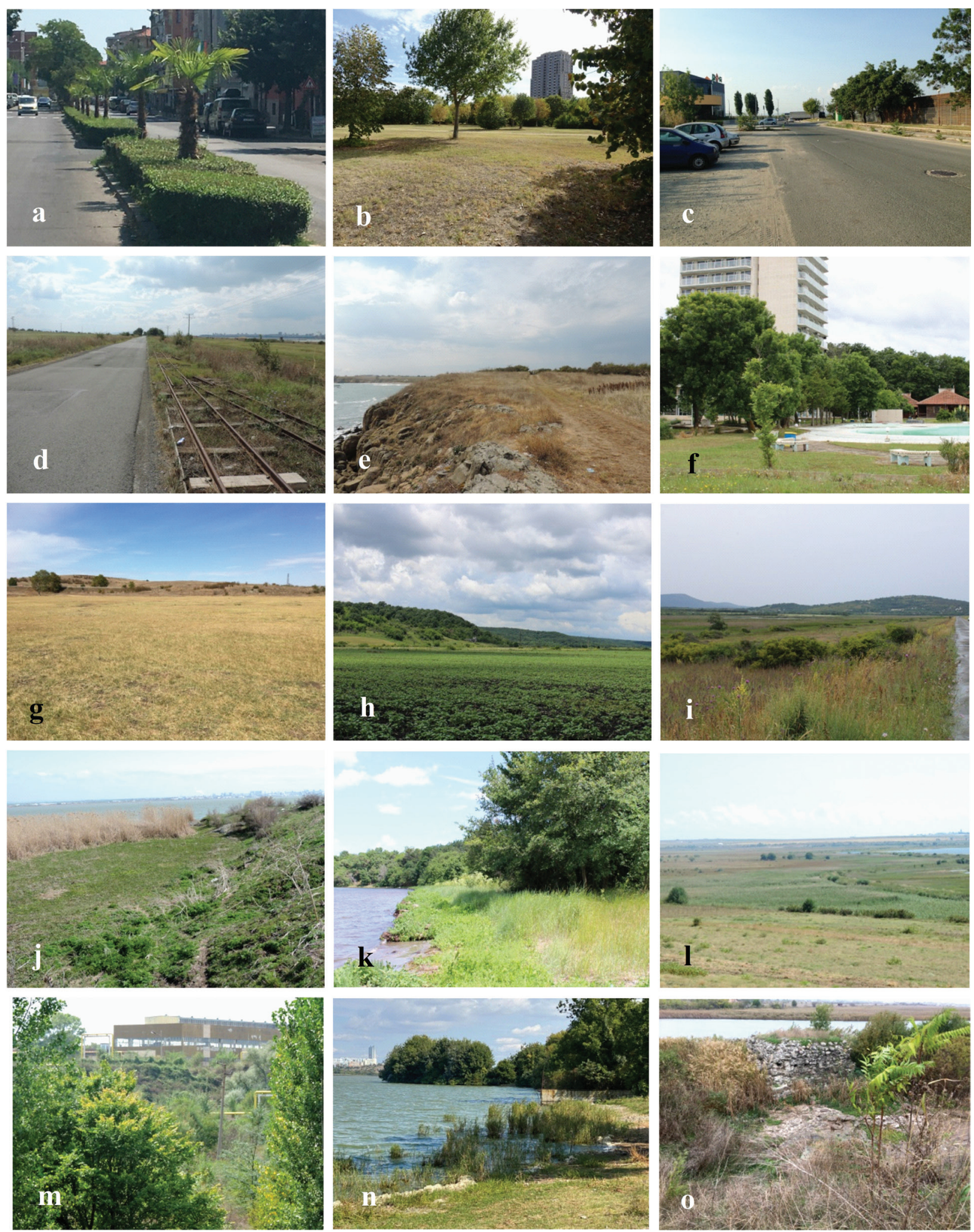

Фиг. 1. $a-h-$ Новочерноморската тераса: $a-$ в гр. Поморие; $b$ - в морската градина на кв. Изгрев, Бургас; $c-$ в южните квартали на Бургас; $d$ - в местността Кюшето, източно от Атанасовското езеро; $e$ - на нос Форос северно от кв. Крайморие; $f$ - при Китен; $g$ - западно от Дебелт; $h$ - между Дебелт и Константиново; $i-l$ - Нимфейската тераса: $i$ - около лимана Алепу; $j$ - източно от Горно Езерово; $k$ - в залива Ченгене скеле; $l$ - северно от Атанасовското езеро; $m$ - предполагаемото местоположение на античното пристанище Деултум върху Новочерноморската тераса; $n$ - античното пристанище Скафида, северно от с. Димчево; $o$ - останки от античната кула Форос до протока между Мандренското езеро и Черно море в местността Пода, южно от Бургас 
та има стена, известна сред местното население като „Рехата“.

\section{Връзка между флуктуациите на морското ниво и човешките дейности}

Новочерноморската тераса е установена на редица места по Южното Черноморие: Поморийския п-в (фиг. 1a); някои квартали на Бургас (фиг. 1bd); нос Форос, северно от Крайморие (фиг. 1е); Китен (фиг. 1f); както и в рамките на Бургаските езера, които по това време са били разклонения на Бургаския залив; Дебелт (фиг. 1g); Тръстиково (фиг. 1h), където палеобреговата линия е ясно изразена, и на много други места. Нимфейската тераса е развита около лиманите, където представлява обрасла с тръстика повърхност на 2 m над съвременното им ниво: Алепу (фиг. 1i), Дебелт (фиг. 1j), Ченгене скеле (фиг. 1k), Атанасовското езеро (фиг. 11) и другаде.

Археологическите артефакти, историческите хроники и флуктуациите на морското ниво са предмет на дългогодишни дискусии, които стават все по-актуални на фона на т. нар. „глобални климатични промени“. Трансгресиите са играли важна роля в древността, осигурявайки връзка на морето с Бургаските езера (Sinnyovsky, 2020a). Образуването на римския полис Деултум през II в. обаче съвпада с Фанагорийската регресия, по време на която морското ниво би трябвало да е най-ниско през последните 7000 г. Историческият музей в Дебелт разполага с артефакти, според които Деултум е бил процъфтяващо антично пристанище, разположено върху Новочерноморската тераса откъм недостроения металургичен комбинат (фиг. $1 \mathrm{~m})$. Странно е, че именно по време на Фанагориийската регресия Мандренският лиман е имал връзка с морето.

Северно от с. Димчево е съществувало и друго антично пристанище - Скафида (фиг. 1n). Според византийските хроники през Средновековието битката при р. Скафида (1304 г.) между войските на Теодор Светослав и Войсил, начело на византийските войски, се е състояла на протока между Мандренското езеро и морето. Първоначално българските войски превземат Созопол, но след това се оттеглят и посрещат византийците при p. Скафида, която е била връзката на Мандренското езеро с Черно море. Според източниците, след преминаването на част от византийците, мостът се срутва и те били разбити. Предполага се, че това е предварително подготвено от българите, а останалата византийска войска се оттегля безславно към Константинопол. Победата е последвана от превземането на Анхиало, Месемврия, Созопол и Агатопол. Съществуването на мост на протока показва, че той не е бил плавателен.
По южния бряг на канала между Мандренското езеро и морето, в местността Пода, върху Нимфейската тераса се намират останките от античната и средновековна крепост Форос с две кули (фиг. 1о), превърната от община Бургас в екозона за отдих, спорт и туризъм.

\section{Заключение}

Очевидно връзката на Мандренското езеро с Черно море е била жизнено важна за древните цивилизации, тъй като е осигурявала интензивен обмен на стоки и товари. Не случайно тук възниква античният град Деултум, който в продължение на столетия е цветущ римски полис. Археологическите артефакти обаче се разминават с данните за холоценските флуктуации в нивото на Черноморския басейн. През Бронзовата епоха морското ниво е било с $4 \mathrm{~m}$ по-високо от днешното, за което свидетелства Новочерноморската тераса в околностите на с. Дебелт. По това време, съвпадащо с началото на елинската колонизация, Мандренското езеро е било продължение на Бургаския залив, просъществувало допреди 4000 г., когато морското ниво спада до днешното. През римската епоха по време на Фанагорийската регресия (основаването на Деултум), то би трябвало да е с 3 m под сегашното. Това поставя редица въпроси около проявата на тази регресия в региона, чиито отговор вероятно се крие в бъдещите по-детайлни изследвания на холоценските утайки.

Благодарности: Настоящото изследване е проведено във връзка с изпълнението на Национална научна програма „Опазване на околната среда и намаляване на риска от неблагоприятни явления и природни бедствия“, одобрена с Решение на МС № 577/17.08.2018 г. и финансирана от МОН (Споразумение № ДО-230/06-12-2018).

\section{Литература \\ References}

Fedorov, P. V. 1956. About the modern epoch in the geological history of the Black Sea. - Dokladi Akad. Nauk SSSR, 110, 5, 839-941, 110, 5, 839-841 (in Russian).

Fedorov, P. V., D. A. Lilienberg, V. I. Popov. 1962. New data about the terraces of the Bulgarian Black Sea shoreline. Dokladi Akad. Nauk SSSR, 144, 2, 431-434 (in Russian).

Popov, V., K. Mishev. 1974. Geomorphology of the Bulgarian Black Sea Coast and Shelf. Sofia, Publ. House of Bulg. Acad. Sci., 267 p. (in Bulgarian with English abstract).

Sinnyovsky, D. 2020a. Holocene transgressions in the area of the Burgas Lakes complex - manifestation of global climatic fluctuations. - J. Mining and Geol. Sci., 63, 1, 243-248.

Sinnyovsky, D. 2020b. Holocene deposits of Varna Lake. $-J$. Mining and Geol. Sci., 63, 1, 249-254. 